\title{
Analysis of the Scientific Thesaurus for Forming Students' Socio- Cultural Values in the Educational Environment of Higher Education Establishment
}

\author{
Zaredinova Elvira \\ ORCID https: orcid.org/0000-0001-6054-3064
}

Ph.D., Associate Professor, Scientific Correspondent, Institute for Problems of

Education of the National Academy of Pedagogical Sciences of Ukraine (Kyiv)

\begin{abstract}
The urgent problem of forming students' socio-cultural values in the educational environment of higher education establishment and the need to analyze its scientific thesaurus have proved in the article. The scientific thesaurus is presented as a system of concepts, which reflects the methodological, theoretical and methodological aspects of the phenomenon under study. There are three groups of concepts that make up the submitted scientific thesaurus: 1) the terms that characterize the methodological aspects of the phenomenon under study (axiological, cultural and environmental scientific approaches, strategic and tactical principles of forming socio-cultural values); 2) the terms that characterize the theoretical aspects of the process of forming socio-cultural values (society, culture, socio-culture, values and socio-cultural values); 3 ) the terms that reflect the methodological aspect of student's socio-cultural values formation (educational environment, environment formation, forms, methods, technologies of forming socio-cultural values).
\end{abstract}

Key words: scientific thesaurus, values, socio-cultural values, educational environment, higher education establishment.

Актуальність дослідження. Ціннісна сфера особистості $є$ iï базовим складником, який набуває особливої значущості в періоди соціальних трансформацій, оскільки цінності є регулятором й мотиватором поведінки. Сучасні глобалізаційні та євроінтеграційні процеси, швидкий темп розвитку суспільства актуалізують важливість у житті людини саме соціокультурних цінностей. Тому що вони визначають самобутність певної культури, яка відрізняє іiі від інших, а також притаманну даній культурі ментальність, унікальність іï культурно-історичного досвіду. Отже, соціокультурні цінності об'єднують соціокультурні особливості певного суспільства, соціальні аспекти різних етнічних груп та певної особистості. Таким чином, $\epsilon$ очевидною синтетична, інтегративна природа феномену соціокультурних цінностей, що має філософське, соціологічне, культурологічне й психологічне коріння (цей аспект соціокультурних цінностей детально висвітлено нами у попередніх працях [2]). Ураховуючи складну міждисциплінарну природу соціокультурних цінностей, а також 
феномену освітнього середовища як площини їх формування у закладі вищої освіти [7; 8; 9; 14; 15], набуває доцільності аналіз наукового тезаурусу досліджуваної проблеми. Варто також відзначити, що одним із суттєвих критеріїв зрілості певної концепції, на думку відомих методологів (Г. Корнетов, В. Краєвський) $є$ обгрунтованість іiі термінологічного апарату, що і зумовлює актуальність зазначеної проблеми статті.

Дослідження соціокультурної та середовищної проблематики представлені такими напрямами, як-от: обгрунтування феномену соціокультури (П. Сорокін); сучасне трактування соціокультурного підходу (Н. Черниш, О. Ровенчак); психологічний формат соціокультурних цінностей (В. Білскі, Г. Олпорт, М. Рокич, Ш. Шварц, Е. Шпрангер); студіювання соціокультурних цінностей $\quad$ у межах дисертаційних робіт (Т. Артімонова, І. Баранова, Д. Даянова, Л. Демідова, O. Карасьова, 3. Назаркіна та ін.); загальнофілософське трактування середовища (B. Корнетов, В. Лепський, I. Тон); концепція середовищного (Ю. Мануйлов), полісередовищного (М. Федорова) підходів у освіті; теорія середовищно зорієнтованого навчання (Ю. Мануйлов, Т. Менг, С. Сергєєв); ознаки середовища (М. Чорноушек); принцип доцільності середовища для людини (В. Міхельсон, Г. Стоколс); імерсивність, присутність й інтерактивність середовища (С. Сергєєв); питання співвідношення понять „середовище” й „простір” (А. Журавльов, Л. Петько, І. Шендрик); типи освітнього середовища: акмеологічне середовище (А. Деркач, І. Соловйов), професійно-креативне середовище (3. Курлянд), інформаційно-освітнє середовище (Л. Панченко); контекстне середовище (О. Щербакова), рефлексивно-освітнє середовище (А. Бізяєва), рефлексивноконтекстне освітнє середовище (В.Желанова); рефлексивно-емпатійне середовище (О. Фаст), рефлексивно-освітнє середовище як умова культурного самовизначення студента (О. Малахова). Проте при такій зацікавленості різними аспектами середовищної проблематики, питання щодо цілісного розгляду наукового тезаурусу проблеми формування соціокультурних цінностей в освітньому середовищі ЗВО залишається дослідженою лише аспектно.

Метою статmі є висвітлення наукового тезаурусу проблеми формування соціокультурних цінностей в освітньому середовищі ЗВО.

Виклад основного матеріалу. 3'ясуємо сутність феномену «тезаурус», що походить від давньогрецького (thésaurós - скарб, скарбниця, запас) й тлумачиться як 
науковий і культурний феномен, який забезпечує порозуміння учених і практиків у світовому освітньому просторі та узгодженість методологічних засад дослідження певних проблем; система понять, що призначені людині для їх засвоєння й актуалізації з метою успішної орієнтації у предметній площині наукових знань [10].

Грунтуючись на поданій дефініції, ми визначаємо науковий тезаурус як систему понять, яка відбиває методологічні, теоретичні й методичні аспекти певного феномену i є засобом для його опису.

Методологічні аспекти феномену соціокультурних цінностей та освітнього середовища ЗВО у контексті їх формування пов’язані з реалізацією ідей аксіологічного, соціокультурного, середовищного наукових підходів. При цьому аксіологічний підхід (I. Бех, Б. Гершунський, М. Євтух, І. Зязюн, В. Кремень, А. Міщенко, В. Сластьонін, Н. Ткачова, Г. Чижакова) ми розуміємо як методологічну стратегію, спрямовану на формування ціннісно-смислової сфери студентів. При цьому відбувається присвоєння студентом об'єктивних цінностей та їх трансформація - в особистісно значущі. Сутність культурологічного підходу (Є. Бондаревська, Б. Гершунський, Е. Гусинський, Н. Злобін, В. Козирев, М. Каган, Ю. Турчанінов, В. Франкл) полягає в трактуванні процесу формування соціокультурних цінностей як засобу становлення людини в культурі. Проте «людина не тільки «споживає» культуру, а й створює їі», тобто людина творить культуру, а культура творить людину. Отже, людина є суб’єктом культури, носієм культурного світопорядку (М. Каган) [3]. Базуючись на ідеях фундатора середовищного підходу до освіти Ю. Мануйлова [4], розуміємо середовищний підхід як освітню стратегію, яка базується на ідеї формування особистості студента, зокрема, його соціокультурних цінностей засобом створення певного середовища. Тобто, впливаючи на середовище й змінюючи його, викладач перетворює середовище на засіб соціокультурного формування особистості студента.

Зазначені підходи конкретизовано в стратегічних (аксіологічної спрямованості освіти; культурно-історичної детермінації освіти; людиноцентризмі; систематичності й послідовності у формуванні аксіосфери особистості; етапності та трансформації цінностей з нижчих на вищі; зв’язку аксіогенезу з професіогенезом особистості; середовищної орієнтації) та тактичних (моделювання змісту, форм і методів формування соціокультурних цінностей; активності; інтерактивності й партнерства; 
задачно-ситуативної насиченості; технологізації) принщипах формування соціокультурних цінностей особистості студента.

Теоретичні аспекти тезаурусу проблеми формування соціокультурних цінностей пов'язані з розглядом соціокультурних цінностей та його семантичних складників (соціум, культура, цінності), а також феномену освітнього середовища.

Беручи до уваги розуміння «соизіуму»- як суспільства, що $є$ цілісною соціальною системою; людською спільністю певного типу (родові і сімейно-споріднені, соціально-класові, національно-етнічні, територіально-поселенські спільності); соціальним оточенням людини, сукупністю форм діяльності людей, що склалися історично [13], маємо відзначити, що семантичний складник соціокультурних цінностей «соціо» акцентує увагу на їх соціальній детермінації на індивідуальному та на надіндивідуальному рівні, ураховуючи вплив як різних соціальних груп, колективів, верств населення, так i суспільства в цілому. Отже, соціальний контекст соціокультурних цінностей пов'язаний з конкретними суспільними умовами певної країни.

Найбільш суттєвими ознаками сучасного українського суспільства, які впливають на процес формування соціокультурних цінностей студентів, є такі, до першооснови суспільного та політичного устрою; вплив на культурний та освітній простір України фундаментальних цінностей громадянського суспільства західної культури, а саме: парламентаризму, пріоритету прав людини, права всіх етнічних груп і національних меншин у складі поліетнічної нації, свободу пересування та інші громадянські свободи, обмеження ролі держави в суспільстві; соціальна стратифікація українського суспільства як «розташування індивідів і груп 3 гори вниз горизонтальними шарами (стратами) за ознакою нерівності в прибутках, власності, рівнів освіти, обсягу влади, професійному престижі, стилі життя» [12]; соціальна мобільність (термін П. Сорокіна), що пов'язана в сучасній Україні 3 масовою міжпрофесійною мобільністю, спадними соціальними переміщеннями; освітня мобільність.

Щодо феномену»,культура», зауважимо, що найбільш доцільними у контексті проблеми дослідження соціокультурних цінностей є нормативні визначення культури, в яких акцентується увага на підпорядкуванні людей нормам, цінностям і моделям 
поведінки. Так американський культуролог Т. Парсонс, відомий як засновник теорії «соціальних систем», з одного боку, розмежовує суспільство і культуру як різні складові людської діяльності, а з іншого - виокремлює структури, утворені на перетині соціальних і культурних систем. Такою структурою науковець вважає соціальну культуру. Т. Парсонс виокремлює два основні компоненти соціальної культури цінності та норми. У соціальному аспекті цінності набувають інтеграційної інтенції, через що Т. Парсонс називає їх «соцієтальними» цінностями. Реалізація культурних цінностей, перетворення їх на норми $є$ актом взаємопроникнення соціальних i культурних систем [5].

Отже, базуючись на окресленій позиції, тлумачимо культуру як соціальне явище в їі аксіологічному вимірі й розуміємо як сочіально зумовлену сферу изіннісних зв'язків, характерних для певного суспільства, щуо є результатом соціальних взаємодій. У цьому контексті соціокультурні цінності є тими аксіологічними орієнтирами, які визначають зміст предметної людської діяльності, а людина стає і об’єктом, і суб’єктом культури.

Стосовно феномену цінностей, варто відзначити, що він є одним із найбільш досліджуваних у сучасному науковому дискурсі. Вітчизняна дослідниця С. Горбатюк зазначає, що «сьогодні в науковому доробку $є$ низка теорій та концепцій, які обгрунтовують феномен цінностей, однак подекуди вони суперечать одна одній, що, власне, підтверджує складність цього поняття в системі філософських і гуманітарних дискурсів, неоднозначність у різних культурних традиціях» [1, с. 22].

Особливу зацікавленість, у контексті проблеми поданого дослідження, викликає трактування цінностей у площині соціокультурної реальності, здійснене у студіях фундатора дослідження феномену соціокультури П. Сорокіна. На думку відомого соціолога, цүінності, як ідеали, норми, смисли, світоглядні орієнтації, $\epsilon$ нематеріальними утвореннями i надбудовуються людством над фізичною та органічною реальностями у результаті розгортання суспільно-історичного процесу [11].

Трактування цінностей як вищих принципів, які забезпечують згоду як в малих суспільних групах, так і в усьому суспільстві в цілому, конструюючи модель соціальної системи, в якій акт людської взаємодії $є$ клітинкою цієї системи, зустрічаємо у Т. Парсонса [6, с. 30]. Відтак, у тлумаченні поняття «цінність» П. Сорокін й Т. Парсонс базувались на позиції, що цінність є продуктом соціальної взаємодії. Саме тому вони 
розглядають цінність через їі складники, а саме: особистість - як суб’єкт взаємодії; суспільство - як сукупність взаємодіючих індивідів; культура - як сукупність цінностей.

Беручи до уваги наукові позиції П. Сорокіна та Т. Парсонса визначаємо сощіокультурні иінності як грунтовні життєві смисли, на яких базується людина у повсякденному житті, у ставленні до навколишньої дійсності й у яких зафіксовано певні моделі соціальної поведінки та особливості певної культури.

Методичні аспекти тезаурусу досліджуваної проблеми відбивають систему умов ефективного формування соціокультурних цінностей в межах освітнього середовища університету. На сьогодні існують такі загальновідомі моделі освітнього середовища, як: антрополого-психологічна модель (В. Слободчиков); комунікативно зорієнтована модель (В. Рубцов); еколого-особистісна модель (В. Ясвін); екопсихологічна модель (В. Панов); психодидактична модель (В. Лебедева, В. Орлов).

У форматі представлених моделей, а також в інших дослідженнях феномену освітнього середовища обгрунтовано такі суттєві властивості освітнього середовища 3ВО, як-от: системність й багаторівневість (В. Слободчиков); відсутність фіксованих рамок у часі і просторі (М. Чорноушек); соціокультурна відповідність (Ю. Кулюткін, В. Мастерова, С. Тарасов); відкритість, комунікативність, «міжсуб'єктна» спрямованість (В. Рубцов, О. Ярошинська); гучкість й варіативність (В. Панов); інтегрованість (В. Лебедєва, В. Орлов); контекстуальність (В. Желанова); діяльнісний характер (Г. Бєляєв); розвивальна спрямованість (О. Писарчук, В. Ясвін).

Ураховуючи окреслені властивості освітнього середовища, трактуємо його як систему різного рівня умов, можливостей та ресурсів об'єктивного та суб'єктивного характеру (соціокультурних, психологічних, дидактичних, просторово-предметних), що цілісно, інтегровано впливають на особистість студента 3 метою розвитку його особистісного потенціалу у всіх важливих сферах (мотиваційній, ціннісно-смисловій, суб' Єктній, комунікативній), формування професійно-особистісних якостей, готовності до виконання соціальних ролей, а також самореалізації як суб'єкта соціуму і культури. Зауважимо, що умови освітнього середовища є динамічними й змінюються залежно від етапів середовищеутворення, які, відповідно меті кожного етапу детермінуються 
певними методами, формами, технологіями формування соціокультурних цінностей студентів в освітньому середовищі ЗВО.

Висновки. У поданій статті висвітлено науковий тезаурус проблеми формування соціокультурних цінностей в освітньому середовищі ЗВО. Ураховуючи трактування наукового тезаурусу як системи понять, яка відбиває методологічні, теоретичні й методичні аспекти певного феномену і є засобом для його опису, а також усталену в науці схему методологічного аналізу, репрезентований тезаурус містить три групи термінів, а саме: 1) терміни, що характеризують методологічні аспекти досліджуваного феномену (аксіологічний, культурологічний, середовищний наукові підходи; стратегічні та тактичні принципи формування соціокультурних цінностей); 2) терміни, що характеризують теоретичні аспекти процесу формування соціокультурних цінностей (соціум, культура, соціокультура, цінності, соціокультурні цінності); 3) терміни, що відбивають методичний аспект формування соціокультурних цінностей студента (освітнє середовище, середовищеутворення, форми, методи, технології формування соціокультурних цінностей).

Перспективним вектором дослідження вважаємо розробку цілісної таксономії наукового тезаурусу проблеми формування соціокультурних цінностей в освітньому середовищі ЗВО.

\section{References}

1. Gorbatyuk S.E. Theory of Values as a Methodological Basis of the Axiology of Socio-humanity Security. Bulletin of the National Academy of Public Administration under the President of Ukraine. Series: Public Administration. 2016. No. 4. P. 20-30.

2. Zaredinova E.R. Socio-cultural Values as an Object of Interdisciplinary Research // Modern Educational Process: Essence and Innovative Potential: Materials Report. Scientific and Practical Conference of Institute for Problems of Education of the National Academy of Pedagogical Sciences of Ukraine, 2016 / ed. by I.D. Bech and Zh.V. Petrochko. Vol. 5. Ivano-Frankivsk: NAIR, 2017. P. 98-104.

3. Kagan MS Philosophy of Culture. SPb. : Petropolis, 1996. 446 p.

4. Manuilov Yu.S.. The Environmental Approach in Education [Text]: dis. ... Dr. ped. sciences: 13.00.01. Moscow, 1997. 192 p.

5. Parsons T. Sketch of the Social System // About Social Systems. Translated from English by A. Harrash. Ed. by V.F. Chesnokova and S.A. Belanovsky. Moscow: Ed. "Academic Project", 2002. P. 545-687.

6. Parsons T. The System of Modern Societies: Translation from English by L.A. Sedov and A.D. Kovalev. Moscow: Aspect Press, 1998. 270 p. 
7. Petko L.V. Vyklyky XXI stolittia dlia osvitnoho prostoru Ukrainy. Naukovi pratsi ChNU: nauk. zhurnal [The challenges of educational space in the $21^{\text {st }}$ century] / Chornom. Nats. un-t im. Petra Mohyly; red. kol.: O.P.Meshchaninov (holova) [ta in.]. Mykolaiv: Vyd-vo ChNU imeni Petra Mohyly, 2017. Vol. 303. Issue 291. P. 10-14.

8. Petko L.V. Vykhovnyi potentsial metodu sytuatsiinoho analizu ( Case study» method) u formuvanni profesiino oriientovanoho inshomovnoho navchalnoho seredovyshcha $v$ umovakh universytetu [Educational potential of the «Case study» method for the forming of the professionally oriented foreign language teaching environment in the conditions of university]. Naukovyi chasopys NPU imeni M.D.Drahomanova. Seriia 17. Teoriia i praktyka navchannia ta vykhovannia: zb. nauk. pr.. Kyiv: Vyd-vo NPU imeni M.P.Drahomanova, 2015. Issue 27. P. 133-140.

9. Pet'ko L.V. Filosofs'ko-lingvistychni idei' rozuminnja mizhljuds'koi' komunikacii' u social'noти seredovyshhi [Philosophical and linguistic ideas of interpersonality communication in professional sphere] / Naukovi zapysky NaUOA. Ostrog: Vyd-vo «Ostroz'ka akademija», 2015. Serija «Filologichna». Issue. 53. P. 353-356.

10. Sysoeva S.O., Sokolova I.V. Problems of Continuing Professional Education: Scientific Research Thesaurus: Scientific Edition / NAPN of Ukraine. - Institute of Pedagogical Education and Adult Education, Ministry of Education and Science of Mariupol State Humanity University. Kyiv: Publishing House "EKMO", 2010. 362 p.

11. Sorokin P.A. Human. Civilization. Society / General editorial, compiler and foreword by A.Yu. Sogomonov: Translation from English. Moscow: Politizdat, 1992. 543 p.

12. Social Stratification [Electronic resource]. URL:

http://uk.wikipedia.org/wiki/Socium. - Title from the screen.

13. Society URL: http://uk.wikipedia.org/wiki/Socium.

14. Pet'ko L.V. Formation of professionally oriented foreign language teaching environment in conditions of university and upbringing of moral and ethical values (on illustration of the phenomenon «honesty» and «lie») Intellectual Archive. 2016. Vol. 5. No. 1 (January). Toronto : Shiny World Corp., Canada. PP. 98-111.

15. Kovalynska I.V., Ternopilska V.I. A Survey of multicultural education in Ukraine: state approach. Science and practice: Collection of scientific articles. - Thorpe Bowker. Melbourne, Australia, 2016. - P. 256-259.

Translation of the Title, Abstract and References to the Author's Language

УДК 378:37.013.42:37.013.43

Заредінова Ельвіра. Аналіз наукового тезаурусу формування соціокультурних цінностей студентів в освітньому середовищі закладу вищої освіти.

У статті доведена актуальність проблеми формування соціокультурних цінностей студентів у освітньому середовищі закладу вищої освіти й необхідність аналізу іï наукового тезаурусу. Представлено науковий тезаурус як систему понять, яка відбиває методологічні, теоретичні й методичні аспекти досліджуваного феномену і $є$ засобом для його опису. Визначено три групи понять, що складають поданий науковий 
тезаурус: 1) терміни, що характеризують методологічні аспекти досліджуваного феномену (аксіологічний, культурологічний, середовищний наукові підходи; стратегічні та тактичні принципи формування соціокультурних цінностей); 2) терміни, що характеризують теоретичні аспекти процесу формування соціокультурних цінностей (соціум, культура, соціокультура, цінності, соціокультурні цінності); 3) терміни, що відбивають методичний аспект формування соціокультурних цінностей студента (освітнє середовище, середовищеутворення, форми, методи, технології формування соціокультурних цінностей).

Ключові слова: науковий тезаурус, цінності, соціокультурні цінності, освітнє середовище, середовищеутворення.

Зарединова Эльвира. Анализ научного тезауруса формирования социокультурных ценностей студентов в образовательной среде учреждения высшего образования.

В статье представлена актуальность проблемы формирования социокультурных ценностей студентов в образовательной среде учреждения высшего образования и необходимость анализа ее научного тезауруса. Представлены научный тезаурус как систему понятий, которая отражает методологические, теоретические и методические аспекты изучаемого феномена и является средством для его описания. Определены три группы понятий, составляющих представленный научный тезаурус: 1) термины, характеризующие методологические аспекты изучаемого феномена (аксиологический, культурологический, средовый научные подходы; стратегические и тактические принципы формирования социокультурных ценностей); 2) термины, характеризующие теоретические аспекты процесса формирования социокультурных ценностей (социум, культура, социокультура, ценности, социокультурные ценности); 3) термины, отражающих методический аспект формирования социокультурных ценностей студента (образовательная среда, средообразование, формы, методы, технологии формирования социокультурных ценностей).

Ключевые слова: научный тезаурус, ценности, социокультурные ценности, образовательная среда, средообразование.

\section{Лimepamypa}

1. Горбатюк С.Є. Теорія цінностей як методологічна основа аксіології соціогуманітарної безпеки. Вісник Національної академії державного управління при Президентові Украӥни. Серія : Державне управління. 2016. № 4. С. 20-30.

2. Заредінова Е.Р. Соціокультурні цінності як предмет міждисциплінарного дослідження // Сучасний виховний процес: сутність та інноваційний потенціал: матеріали звіт. наук.-практ. конф. Ін-ту проблем виховання НАПН України за 2016 рік / за ред. І.Д. Беха, Ж.В. Петрочко. - Вип. 5. Івано-Франківськ : НАІР, 2017. С. 98-104.

3. Каган М.С. Философия культуры. - СПб.: Петрополис, 1996. - 446 с.

4. Мануйлов Ю. С. Средовой подход в воспитании [Текст]: дис. ... д-ра пед. наук: 13.00.01. Москва, 1997. 192 с. 
5. Парсонс Т. Очерк социальной системы // О социальных системах; пер. с английскогоА.Харраша / под ред. В.Ф. Чесноковой, С.А.Белановского. - Москва: Изд. «Академический проект», 2002. С. 545- 687.

6. Парсонс Т. Система современных обществ: пер. с англ. Л. А. Седова, А. Д. Ковалева. Москва: Аспект Пресс, 1998. 270 с.

7. Петько, Л. В. Виклики XXI століття для освітнього простору України. Наукові прачі [Чорноморського державного ун-ту імені Петра Могили комплексу "КиєвоМогилянська академія"]. Серія: Педагогіка : наук. журн. / Чорном. держ. ун-т імені Петра Могили; ред. кол.: О.П.Мещанінов (голова) [та ін.]. Миколаїв: Вид-во чНУ імені Петра Могили, 2017. Т. 303. Вип. 291. С. 10-14. URI http://enpuir.npu.edu.ua/handle/123456789/9455

8. Петько Л.В. Виховний потенціал методу ситуаційного аналізу («Case study» method) у формуванні професійно орієнтованого іншомовного навчального середовища в умовах університету. Науковий часопис НПУ імені М.П.Драгоманова. Серія 17. Теорія і практика навчання та виховання : зб. наук. пр. ; за ред. академіка В.І.Бондаря. Київ: Вид-во НПУ імені М.П.Драгоманова, 2015. Вип. 27. С. 133-140.

9. Петько Л.В. Філософсько-лінгвістичні ідеї розуміння міжлюдської комунікації у соціальному середовищі. Наукові записки Національного університету «Острозька академія». Серія «Філологічна»: зб. наук. праць / укл. І.В.Ковальчук, Л.М.Коцюк, С.М.Новоселецька. Острог: Вид-во Національного ун-ту «Острозька академія», 2015. Вип. 53. С. 309-312.

10. Сисоєва С.О., Соколова І.В. Проблеми неперервної професійної освіти: тезаурус наукового дослідження: наук. видання / НАПН України. Ін-т пед. освіти і освіти дорослих, МОН. Маріупольський держ. гуманит. ун-т Київ: Видавничий дім «ЕКМО», 2010. 362 с.

11. Сорокин П.А. Человек. Цивилизация. Общество / Общ. ред., сост. и предисл. А. Ю. Согомонов: Пер. с англ. - М.: Политиздат, 1992. - 543 с.

12. Соціальна стратифікація [Електронний ресурс]. URL:

http://uk.wikipedia.org/wiki/Соціум. - Назва з екрана.

13. Соціум URL: http://uk.wikipedia.org/wiki/Соціум.

14. Pet'ko L.V. Formation of professionally oriented foreign language teaching environment in conditions of university and upbringing of moral and ethical values (on illustration of the phenomenon «honesty» and «lie») Intellectual Archive. 2016. Vol. 5. No. 1 (January). Toronto : Shiny World Corp., Canada. PP. 98-111.

15. Kovalynska I.V., Ternopilska V.I. A Survey of multicultural education in Ukraine: state approach. Science and practice: Collection of scientific articles. - Thorpe Bowker. Melbourne, Australia, 2016. - P. 256-259. 